\title{
Nationalism, ethnicity and religion: fundamental conflicts and the politics of identity in Tanzania
}

\author{
JOHN CAMPBELL \\ Department of Sociology and Anthropology, University of Wales, Swansea \\ SA2 8PP
}

\begin{abstract}
This article explores the competing relations between ethnic, religious and racial identities in contemporary Tanzania at a time of rapid socioeconomic change and in the face of the declining authority and legitimacy of the state. During nearly four decades of one-party rule the state has pursued policies - educational, linguistic, developmental, etc. - aimed at constructing a secular national identity capable of uniting diverse social groups under the banner of African socialism. However, economic retrenchment in the 1980s and political liberalisation in the 1990s has contributed directly to a series of upheavals leading many Tanzanians to redefine the structures of common difference and to a fracturing of national identity. This article seeks to understand the reasons for the upsurge of conflict and cultural fragmentation in the 1990s.
\end{abstract}

This article is concerned to understand the processes which underlie social and cultural fragmentation and conflict in Tanzania. In particular, I seek to understand what appears to be an inherent contradiction between local conceptions regarding the civic-territorial model of secular national identity which the ruling party attempted to construct and impose on its citizens, and more 'fundamental' notions of social identity based on ideas of ethnicity and religion which pre-date the formation of the modern state.

I begin by reviewing the efforts of the former one-party state to construct a shared sense of citizenship and national identity. The collapse of these effort's in the 1980s is, I argue, important for understanding current antipathies and escalating religious, ethnic and racial strife. I then examine events surrounding a 1993 'Muslim riot' in terms of three major factors which underlie rapidly changing relations between Muslims and Christians. These factors are (i) differential access to formal, secular education and to employment; (ii) Christian and Muslim appreciation of education; and (iii) their varying degrees of involvement in and commitment to secular government programmes.

However, underlying popular discourse about religious 'fundamentalism' 
is a concern about growing socio-economic inequality. Social understandings about race, ethnicity and religion are deeply intertwined with longstanding patterns of elite politics and local perceptions about inequality. The collapsing authority of the ruling party brought not only economic stagnation but also political liberalisation and multiparty politics. Official censorship ended with the one-party state, and a thriving local press and media has developed providing a means for the dissemination of ethnic, racial and religious views which has promoted cultural and religious chauvinism.

\section{The rise and demise of Tanzanian national identity, 1961-1986}

Tanganyika African National Union (TANU), the nationalist party which won the referenda on independence, was formed in 1954 as an amalgam of political and ethnic groups who supported Julius Nyerere's programme for African self-rule. A key feature of Nyerere's programme was an ideology which centred on the moral qualities of the individual and the egalitarian nature of Tanganyikan African society.

In 1961 TANU, with Nyerere - a British-educated Roman Catholic and Fabian socialist - as prime minister, came into power. The early sixties saw the party build up its organisation at the same time as it shifted from a gradualist, voluntaristic and incremental development strategy towards a transformationalist approach which emphasised equality, democracy and socialism (Yeager 1989; Hedlund and Lundahl 1989). The economic situation stymied the nationalist programme of Africanisation of the civil service and indigenising the economy; problems were further compounded by the 1964 Union with Zanzibar which linked the latter's racial and ethnic tensions to Nyerere's as yet ill-defined programme of nation-building. The 1967 Arusha Declaration restated the centrality of the party in achieving agricultural self-reliance through a programme of mass participation and equality in the distribution of national wealth, but set in motion two contradictory processes. First, a growing centralisation of power in state and party institutions - i.e. the creation of a one-party system, reform and centralisation of local government, control over trades unions, military and police, and the authority of party over government, etc. - was put into place, which ensured compliance with central policy directives. Second, there occurred an elaboration of a socialist ideology which entailed the nationalisation of the economy and moral exhortations to citizens to work hard to realize ujamaa ['familyhood', but often translated as socialism] (F. Burke 1964; Nyerere 1964).

Ujamaa revolved around domestic policy, and in particular educating and mobilising the population of approximately 120 ethnic groups around the party to achieve agricultural self-reliance. Educational reform was both structural and curricular. Integrated non-racial education was instituted 
early, followed by major investment in primary, secondary and postsecondary education to expand access to Africans (Kaduma 1974). At the same time, free primary education was made universally available, and adult and technical education was initiated.

The 1967 'Education for Self-Reliance' policy called for major changes in the educational curriculum to promote Tanzania's political philosophy (through promotion of Swahili as a national language and through special courses), vocational training (especially in agriculture), changes in the organisation of the schools, and increased party control over access to higher education.

By the late seventies the 'social control element of educational policy ... [represented] the attempt to build up and diffuse mass understanding and internalization of those common attributes that together form the basis of Tanzanian citizenship' (Court 1979: 214). An emphasis on reduced elite privileges, on leadership responsibility, social justice and equality, the dignity of labour, etc. were to be pursued in a non-racial, secular fashion under party guidance. On the one hand, educational policy was intended to provide the training necessary to transform agriculture; on the other hand, transformation was to be accomplished through inculcating the basic tenets of citizenship and national identity as envisaged by Nyerere. It was, in short, the intention that public education would turn peasants into modern Tanzanians.

A major part of the effort to create and foster a sense of political consciousness and national identity involved the promotion and use of Kiswahili in public education and national politics. While Kiswahili had evolved as the language of trade during the colonial period, it was in fact the first language of a relatively small population resident on the north Kenyan coast and off-shore islands. The task of standardising Swahili began in 1930 when the British established the Inter-Territorial Language Committee to promote the Zanzibar dialect for Territorial adoption (Blommaert 1996). Despite its use and promotion by the German colonial administration, knowledge of Kiswahili was limited to the coast and to towns. The British also established a Swahili press (Scotton 1978).

TANU appears to have adopted Swahili shortly after the party was formed, probably to communicate with its diverse ethnic membership; 1962 was the first time that Nyerere addressed the Bunge (parliament) in Kiswahili - rather than in English - making an important symbolic and political statement about African culture (Khamis 1974). However, it was only in 1968 that Kiswahili became the official language for politics/administration and for instruction in primary schools and adult education (it was subsequently used in high schools to teach history and political education).

While it is true, as Blommaert (1996: 250) has argued, that the official position on Kiswahili was far less radical in its sweep than some nationalists liked, it would be incorrect to assume that efforts to develop cultural nationalism were in any way limited to the schools. Specifically, the 
erstwhile Ministry of National Culture and Youth operated a range of cultural programmes including: museums; sport; film censorship; theatre; and Swahili language promotion (Mbuguni and Ruhumbika 1974). In addition, there were political education classes, paramilitary training for the people's militia, as well as an expanded role for the party in industry and in schools (i.e. the TANU Youth League) to propagate and inculcate socialist values and attitudes through Kiswahili. After the announcement of the Mwongozo or Guidelines for TANU officials in 1971, efforts were also made to develop Swahili terms to facilitate a vernacular 'class analysis'.

In retrospect, while the above efforts fell short of creating a 'national culture' seen as 'the sum total of a people's way of life in their effort to live, to continue living and to develop as a nation' (Mbuguni and Ruhumbika 1974: 275), the party had set out to construct a 'modern nation' along these lines. Nyerere's moral exhortations, together with policy pronouncements, were clearly aimed at realising a society based around a 'new man': anticapitalist, egalitarian, a hard worker and responsive to moral rather than material incentives. Such a person would, in leaving behind particularistic ethnic concerns, adopt a new national culture as represented in part by Kiswahili (at that time a symbol of national unity and socialism) (Khamis 1974: 294; Hedlund and Lundahl 1989).

Thus the party increasingly took up the idea of nation-building or kujenga taifa (literally 'to construct a nation') rather than creating a homogeneous national culture as the basis for garnering public support for its policies and programmes (Blommaert 1996). However, the ideology of nation-building underpinning ujamaa began to come unstuck on a welter of internal contradictions - e.g. authoritarian and hierarchic educational practices, a lack of correspondence between educational qualifications and opportunities in the labour market - and the evaporation of meaningful mass participation in, and local accountability of, government. In addition, development programmes faltered as the party moved to enforce villagisation/ resettlement, communal production, rural cooperatives, etc. compliance with its policies (e.g. Boeson et al. 1977; Yeager 1989). Further, by the late $1970 \mathrm{~s}$ it was becoming apparent that government policies were directly contributing to economic stagnation, inflation and commodity shortages, and corruption. Indeed, the growing inefficiency of public institutions was matched by a doubling of dependence on foreign aid between 1969 and 1983, a situation made worse by the cost of the Ugandan war, worsening terms of trade and declining agricultural production.

The period from the late 1970s to the mid-1980s was one of increasing economic hardship and growing public scepticism of government in the face of a continuing socialist rhetoric and state inefficiency. Significantly, while the national economy collapsed an unprecedented growth in the public sector occurred which substantially increased civil service and party jobs (Yeager 1989: 76).

Structural adjustment policies adopted in the mid-1980s involved major 
funding cuts in education and health; urban unemployment and poverty increased substantially (Helleiner 1987). The party's achievement was to create employment for graduates of the public school system, the vast majority of whom were Christians from up-country areas. Despite the key role given to the educational system by nationalists, structural adjustment resulted in a massive drop in school attendance (from 93 per cent in 1980 to 74 per cent in 1990), and rising failure and drop-out rates (24.2 per cent and 25-30 per cent, respectively). ${ }^{1}$ The very instrument chosen to construct civil society and national identity was collapsing, while growing social inequality was undermining national unity.

The unravelling of socialist policies brought to a halt efforts to mould national identity and political consciousness. While a generation of children - between 1968 and 1978 - did, to varying degrees, become 'cultural nationalists', events subsequent to their departure from school altered their outlook and orientation. Indeed, by the mid-1980s it was the beneficiaries of this political and educational system who led opposition to single-party rule.

In effect, ethnic, religious and racial attitudes from the pre-colonial period resurfaced beginning with social cleavages between immigrant ethnic groups (i.e. Persian 'Shirazi', followed by Omani Arabs and south Asians) and Africans (Nimtz 1980: ch. 3; Pouwels 1987; Amiji 1969). Concern about immigrants reappeared in the form of racial tensions concerning social inequality.

During the colonial period a massive migration of watu wa bara or upcountry Africans to coastal towns occurred, a process which displaced local African Muslims, fuelled religious resentment, and gave an impetus to new forms of urban social organisation, status and identity (Campbell forthcoming). In the 1940s and 1950s African nationalism fed off perceptions of Asian racial difference and privilege and, at roughly the same time, access to secular education became systematically linked with access to waged work and wealth.

Waged work is predominantly located on the coast and in urban centres. Contrary to Issa Shivji, the growth of wage labour did not result in a class system (1986). Instead, the labour market affected a small percentage of the national population - for example factory, workers numbered 52,000 in 1952 rising to 66,000 in 1966 - exhibited great geographic and workplace dispersal, and had a brief history of labour organisation marked by cooptation and control by the state (ibid: 114). In addition, while the number of wage employed people rose greatly as a percentage of the urban population, by 1991 it had peaked at approximately 36 per cent and has since declined (Tripp 1997: 31).

As important as urban wage-based occupations may have been to a small percentage of the population, with the significant exception of the urban middle class there is little evidence that class provided an enduring collective identity. Following Smith, in Tanzania 'the limited emotional appeal and lack of cultural depth' of class arises partly from the fact that most urban 
workers are rural migrants for whom local/regional attachments remain important (Smith 1991: 5). Because urban incomes were tightly controlled by government inflation and structural adjustment eroded urban incomes to the point where individuals survived by pursuing multiple forms of self-employment (Tripp 1997). This is not to argue that, from time to time and with respect to particular professions, class or occupation has no social or political salience, only that class has not formed the basis of a collective identity in any way comparable to ethnicity and religion.

Thus, despite attempts to create an overarching national identity and reshape what it saw as the primordial, anti-modern pull of ethnic, cultural and religious sentiment, by the late 1970s these latter identities were once again resurfacing. At the same time many beneficiaries of national development - artisans, shopkeepers and others with more tenuous livelihoods - were now facing an ambiguous and uncertain future. Together with a large and growing urban population of unemployed and growing numbers of casual labour, a large urban social strata exists which is attracted to populist appeals and religious 'fundamentalism'. For the urban poor, fundamentalism offers a vision of the world 'turned inside out', that is, a vision of a future untainted by political failure (Gilsenan 1982: ch. 10).

Contemporary Tanzanian politics is organised around thirteen political parties, most possessing only a regional and/or ethnic political base (van Cranenburgh 1996). Apart from opposing Chama Cha Mapinduzi (CCM, formerly TANU), the other parties have poorly articulated programmes, a fact which contributes to a sense of social fragmentation as politicians argue over 'indigenisation', the economy, corruption and the state of the Union with Zanzibar. The country's 120 ethnic groups (excluding Asians) are generally small and are equally divided between Islam, Christianity and animism. And Dar es Salaam, where the Bunge is located, is itself a large multiethnic, multifaith conurbation where the differences between rich and poor are easily observed and where ethnicity and religion are important, observable facets of daily life (Campbell et al. 1995).

Political liberalisation saw the development of a thriving local press which competes with the semi-official national English language daily The Daily News and The Daily News on Saturday. Until the mid-1980s the latter two papers constituted the English language press and possessed a reputation for idiosyncratic reporting which often revealed government incompetence, though they always cleaved to the government line in their commentary and construal of events. The government and CCM also publish and distribute other official and semi-official Kiswahili newspapers (e.g. Uhuru).

Since 1990, an independent press has developed which includes several privately owned English language newspapers (e.g. The Tribune, Business Times, The Express) and monthly magazines (e.g. Change, Weekly Mail). Some publications are connected to specific political parties and/or wealthy, influential individuals. In recent years the 'Swahili press' (e.g. Mwananchi, 
Bahari, Majira, Rai, Shaba, etc.) has also grown and reports both official and private views. Standards of writing and reporting vary widely, as does the extent to which editorial opinion is independent of partisan political interests. It was the independent press which 'countered the perpetually onesided reporting of the state-owned print media, exposing popular resentment of corruption and abuse of power within CCM' (Chege 1994: 54).

Until recently radio was government owned and, with the exception of Zanzibar, neither terrestrial nor satellite television existed. In the early 1990s, a small privately owned FM station was established in Dar es Salaam and, in time to cover the Gulf War in 1991, two privately owned terrestrial channels - one African, the other Asian-owned - were set-up. In 1993 the television stations were also caught up in rising racial and ethnic tension as the Asian station owner allegedly threatened to blow up the African-owned station. $^{2}$

On 23 January 1993 the newly formed but unregistered Democratic Party (DP) held a political rally in Dar es Salaam as part of the run-up to multiparty elections in 1995. At the rally 'thousands of people, mainly youths' came to hear

party leader Reverend Christopher Mtikila deliver an emotional speech complaining of alleged exploitation by the businesses of Asian origin. He also reiterated his rejection of the Tanzanian Union. After the rally some youths pelted cars driven by people of Asian origin. ${ }^{3}$

Immediately following the 'riot', CCM publicly condemned so-called 'DP political thuggery'. Shortly thereafter, the 'self-styled Reverend' Mtikila found himself in court charged with sedition, illegal assembly and attempting to cause a breach of the peace. He was alleged to have told the rally that 'Tanzania had been sold away and walala hoi (mainlanders) were deprived of their wealth by people of Asian origin'; that 'Zanzibaris and people of Arab origin should leave the country immediately'; and that 'all CCM leaders were bandits'. ${ }^{4}$

Rev. Mtikila was released on bail on 9 February though both he and his party were to face continuing difficulties in court and in obtaining legal recognition. The statements attributed to him refer to a controversy regarding Zanzibar's contravention of constitutional provisions federating the mainland and the islands of Zanzibar and Pemba when it unilaterally joined the Organization of Islamic Conferences. Remarks about exploitative Asians refer to long simmering African nationalist allegations that all Asian businessmen were/are involved in the black market, with illegal drugs, etc. and in buying influence and protection. Both accusations draw attention to pivotal political questions of the mainland's relationship to ('Arab' and Muslim) Zanzibar, and the relationship between mainland Africans and Asians in running the national economy.

Public scrutiny of the relation between politics, religion and ethnicity extended well beyond electoral issues, to include allegations that the minister 
of finance had erected a mosque in the Treasury at taxpayers' expense; the dismissal of school children in an up-country school allegedly because of 'tribalism'; and concern about the Islamic Republic of Iran's funding of rural development in a Muslim coastal district. ${ }^{5}$

\section{Rampaging Muslims: the 1993 riot in context}

Prior to examining the riot it is instructive to briefly examine the historical development of Islam in Tanzania. Following limited proselytisation in the nineteenth century, a major wave of Islamic conversion occurred between 1904 and 1924 due to the dislocation caused by war, the consolidation of the German colonial state, and the message of the new faith (Trimingham 1964; Nimtz 1980). Until the 1930s, coastal towns like Dar es Salaam were predominantly Muslim which meant that as increasing numbers of upcountry migrants arrived tension between Muslims and Christians grew (at a time when to be Christian was seen as being anti-Muslim) (Anthony 1983: 181). Religious conversion was facilitated through Sufi brotherhoods who employed heterodox ritual practices which exhibited 'African' cultural elements and which bypassed 'Arabs', whom Africans believed were blocking their access to Islam.

There is little doubt that the recency of African conversion to Sunni Islam means that this community is quite different from of Ibadhi Arabs (now localised in Zanzibar) and from the urban-based Asian Shia communities (Amiji 1969; Schildknecht 1969). The Muslim community in East Africa confronts a double contradiction: on the one hand, effective religious organisation lies with the Shia, on the other hand, the Sunni-Shia division is 'racial'. Sect, class and race intersect with the result that division rather than consensus prevails amongst Tanzanian Muslims. The crucial point is that Asians occupied the middle tier of the colonial racial hierarchy expressed in a system of racial segregation and socioeconomic stratification. Their visibility, corporate organisation, the increasingly closed nature of their communities and their apparent affluence meant that Asians became the object of African animosity.

At the height of the Africanisation of the civil service and indigenisation of the economy in the 1960s government created the Supreme Council of Tanzanian Muslims (BAKWATA) to bring together all Tanzanian Muslims - Sunni and Shia, African, Asian and Arab - to assist Muslim Africans. There appears to have been two very different perceptions guiding the creation of the council: government interests in integrating and controlling a large Muslim population, and the aspirations of a very diverse Muslim community for assistance and to articulate their own interests (Constantin 1994). In the absence of organised Muslim political parties and recognised Muslim leaders, the Council has attempted to co-opt local Muslims and incorporate them into clientelist political networks. 
In 1981, BAKWATA was accused of inefficiency and corruption by President Aboud Jumbe of Zanzibar, who unsuccessfully attempted to bypass it and create a second national council. Jumbe, apparently with support from the Islamic World League, lost his bid in part because his authority was based on his government post which he subsequently lost (Constantin 1993: 50). In addition, BAKWATA has been challenged by several short-lived Sunni associations including the conservative All Muslim National Union of Tanganyika in the mid-60s (Chande 1993); the Iranianinfluenced Tanzanian 'Preachers of Islam' (who were deported from Mombasa following riots in 1987 and who are banned from speaking in Tanzanian towns); and, most recently, by the Quran Development Council (BALUKTA) based at Mtoro mosque in Dar es Salaam (see below; Chande 1993: 52, n. 27; Balda 1993: 230, n. 17).

In January 1993, fasting for Ramadan began and lasted until 24 February when special prayers were called in the mosques of Dar es Salaam to mark the breaking of the fast. The president of Tanzania, himself a Muslim, attended prayers at State House at which the chief kadh of Tanzania urged religious tolerance. On 9 April, Good Friday was marked nationally in Dar es Salaam by Christian services at which a bishop called for 'peace and tolerance'. ${ }^{6}$ However, while Christians were in church, Sheik Yahya, a Sunni and leader of the Quran Development Council of Tanzania (BALUKTA), allegedly incited Muslims at the Magomeni Islamic Centre in Dar es Salaam to 'demolish all Dar es Salaam pork butcheries'. According to the police, crowds converged on the Islamic Centre in Kigogo while others attacked and demolished nearby pork shops, following which rioters returned to the Centre to be congratulated by their leaders who resolved to continue the attacks the following day. ${ }^{7}$ Subsequently thirty-eight people were charged with 'rioting' and illegal assembly, and Sh. Yahya was detained under a government crackdown on 'Muslim fundamentalists'.

The chief kadh, speaking on behalf of the Council (BAKWATA), immediately denounced the riot. At the same time, Mtoro mosque, with which Sh. Yahya was reputedly linked, disassociated itself from him and the riots. However, the continued detention of the sheik and his 'followers' led to a subsequent 'Muslim demonstration' outside the court resulting in charges being brought against twelve more individuals for an illegal demonstration 'to force the release of 30 other Muslims'. ${ }^{8}$

\section{Attribution, allegation and misrepresentation: unravelling contemporary truths}

Following the riot non-Muslims began attributing responsibility for certain events to 'Muslim fundamentalists' which had no basis in fact; however, this web of allegation and accusation became nearly as important as the events themselves. Immediately after the riot, and while members of BALUKTA remained in jail, BAKWATA held a national Muslim convention attended 
by African Sunni, Asian Shia and Asian Memon and Baluchi representatives and financed by private donations. ${ }^{9}$

In June 1994, forty-three students at a Catholic Girls' Secondary School died in a fire, and this was followed by an arson attack against a second Christian boarding school. In July 1994, police used teargas to disperse 'fundamentalists' at a Mosque in the town of Morogoro where a year earlier three Sudanese imams were deported for 'preaching intolerance'. ${ }^{10}$ Perhaps unsurprisingly, seventeen months after the'pork butcheries' riot, two more imams joined the sixteen individuals in jail still awaiting trial for the riot. ${ }^{11}$

Predictably in July 1994 the issue of public discussion was MuslimChristian relations and in particular the allegation that Muslim 'fundamentalists' were involved in arson attacks. Given the historic exclusion of Muslims from secular education and the prominence of Missions in providing secular education, such allegations were a logical extension of Christian fears.

Fear and distrust were palpable among middle-class, educated Tanzanians who earnestly discussed schisms which had developed between longtime friends, some of whom suddenly, it was said, had declared themselves to be Muslim and had terminated personal and professional relationships with Christians. Christians alleged that Muslims had burned down a church in Kibaha and threatened to bomb a cathedral. Worst of all, the government, and especially the (Muslim) president, stood accused of turning a blind eye to such activities, and in effect encouraging fundamentalists!

Local opinion unequivocally linked the rise of 'fundamentalism' - by which they meant the rapid growth of religious (Muslim and evangelistic Christian) organisations - to the economic liberalisation initiatives of 1984. This was also the year Nyerere stepped down from the presidency and personally nominated his successor Ali Hassan Mwinyi - a Muslim with strong connections to Zanzibar - who was duly elected. While the 'pork butcheries' incident was seen as signposting a fundamental shift in Christian-Muslim relations, the question which went unasked was, how such a situation had come to pass?

One contributory factor was the public school system established by the Christian missions which sought to by-pass/contain areas dominated by Islam. Because Ibadhi Arabs did not proselytise Africans, conversion was restricted to the coast. Indeed, away from the coast and with the exception of Uganda, there was no noticeable Islamic proselytisation until the 1890s, roughly the same time that Christian missions first began to experience success (Oliver 1970: 203). Interestingly, the major Islamic influence in the interior was not Arab traders but the presence of German East African (Sudanese Muslim) soldiers and coastal Muslim Swahili officials of the German colonial administration.

European missionaries were acutely aware of the expansion of Islam in the years preceding World War I. However, while the missions attempted to check the advance of Islam by strategically opening stations or posts to 
fence-in Muslim enclaves, they were also competing amongst themselves for adherents (Iliffe 1979: 218ff.; Oliver 1970: 207). It appears that the consolidation of colonial control provided a foundation for the expansion of Christianity and Islam. The success of missions in gaining adherents had been indifferent until this time, perhaps because many had been established as relatively closed communities - the Roman Catholics, for example, built missions to minister to freed slaves (Versteijnen 1968).

One major reason for the phenomenal growth of Christianity between 1914 and 1944 stemmed from the growing demand for formal education which only the missions provided. State education was slow to develop and limited in scope, nearly always working together with the missions and predominantly focused in towns and up-country non-Muslim areas. In part this had to do with ad hoc colonial accommodations with local Muslim clergy who mistrusted 'secular' schools (Elmasri 1987; Sperling 1993), but by and large government, deliberately or otherwise, failed to make education available to Muslims.

The end result of this policy, pursued consistently through to the present, has been to restrict Muslims to Koranic schools condemning them to unskilled and poorly paid work (Lockwood 1989: 177ff.) at the same time as their home districts remained undeveloped. The historic character of religious conversion is such that in the popular imagination specific ethnic groups are perceived to be either Muslim or Christian, a distinction which corresponds roughly to that between the uneducated and educated, and to the geographic division between the coast and the interior.

It is worth discussing the very different attitudes that Muslims and Christians have towards education and educational reform. The vast majority of Tanzania's African Muslims are Sunni and were converted largely through the work of a small number of Sufi tariqa or brotherhoods after 1870 (Nimtz 1980: ch. 3). In some cases the tariqa, organised around a sheik and his murid (disciples), arrived after Islam had already been introduced to the area and helped to 'deepen the commitment of Muslims to their religion'. In other cases the tariqa was the agent for conversion (ibid: 65).

In the words of Lamin Sanneh, Islamic reformers in Africa have sought to 'sacralize ... the cultural milieu that properly conveys the mission of Islam' (1994: 33); in effect this meant enhancing 'the primacy of Arabic in scripture, law and devotion' which alone provides the convert with the means to understand and participate in Islam. Muslim scriptures are, therefore, non-translatable and must be approached through a proper understanding of Arabic. In East Africa, as elsewhere, important exceptions to this tenet have arisen from the manner in which Islamic conversion was achieved.

One area of controversy within Islam concerns the role of the Sufi tariqa and its accommodation to local (African) culture in the form of dhikr ritual - a continuous repetition of various words or phrases in praise of God 
accompanied by 'African' drumming and dancing, which is said to result in the achievement of an ecstatic state (Nimtz 1980: ch. 4; Parkin 1994). Despite the appeal of dhikr for converts - which has had marked success since at least the early 1930s - it is seen as a heresy by Zanzibar-based Wahhabi reformers who belong to the Ibadhi sect (Parkin 1995). However, as an example of cultural hybridity, dhikr is a typical accommodation to local conditions and has occurred widely as part of the process of Islamisation.

Another important deviation from Sunni religious tenets concerns the crucial role played by Kiswahili in the propagation of Islam in East Africa. Balda notes that some Sunni leaders have insisted on the adoption of Kiswahili, as opposed to Arabic, as the means of reaching and educating East Africans, since this is the regional lingua franca. Kiswahili is in fact the medium of Islamic education in madrasa (schools) throughout the region.

In the absence of a consensus within the East African Muslim community, conflicting positions have been taken over the use of Arabic versus Kiswahili: while some continue to insist that Arabic should be the language for teaching and propagating Islam, others systematically employ Kiswahili to write about Islam and to instruct believers in the Islamic faith. In part, this split represents a cultural predisposition of East African Muslims and the linguistic dominance of Kiswahili, in part it represents factional differences over the authenticity of divergent interpretations of faith/ scripture, and in part it represents growing political differences over acceptance of the secular status quo separating religion and politics (Balda 1993: 237). Indeed, the first translation of the Koran into Kiswahili occurred in 1953 (by the Ahmadiyya sect) and was followed by subsequent translations by Sh. Abdallah Saleh Farsy; both translations fanned the debate even as it made the Koran accessible to East Africans (Trimingham 1964: ch. 3; Elmasri 1987).

Christianity, on the other hand, has long been noted for its efforts to translate the Bible into vernacular languages as a means of gaining adherents, a process which led to the indigenisation of the church (Sanneh 1994). This process was based partially on the importance of literacy for reading the Bible, which gave Christianity its authority, and upon the militant fervour and organisational strength of village catechists and evangelists who preached 'a Manichean view of the world as a struggle between light and darkness' in which non-Christian customs had no place (Iliffe 1979: 227). Unlike Muslims, Christians saw good vernacular translations as facilitating propagation of the faith.

Differential access to formal education had the effect of structuring inequality in the labour market and, together with fundamentally different attitudes toward education in Christian and Muslim communities, has gone hand-in-hand with a quite different involvement in secular politics by Christians and Muslims. For example, one effect of nearly thirty years of one-party governance was to limit political opposition. Unions, agricultural 
cooperatives, local government, religious organisations, even households were integrated into the party. In part this led to growing public disaffection as CCM became increasingly unresponsive; and in part it gradually resulted in the delegitimisation of the institutions coopted by CCM.

Muslim involvement in national politics has been quite different from that of Christians in that the larger churches have their own development programmes to assist local parishes. Muslims, on the other hand, were enrolled in the construction of ujamma through the Sufi tariqa. Because the brotherhoods were successful in promoting the interests of African members against the Arab 'ulama, they became the organisational basis for local African politics and played an important role in mobilising political support for TANU in the 1950s and 1960s (Nimtz 1980: 184). The establishment of BAKWATA in the 1960s may in the long run have undermined the creditability of local sheiks through their association with an increasingly ineffective government.

Locked increasingly into official programmes, the extent to which sheiks have become discredited in the eyes of their followers depends upon local perceptions about the benefits of government programmes. In the 1960s, Muslims assumed that an African government would make a significant difference to their lives through development programmes and the elimination of Indian and Arab economic power (Nimtz 1980: 188). In recent years, however, 'foreign' economic influence has grown with the opening-up of the economy under structural adjustment.

Recently the authority of local sheiks is likely to be undermined by the arrival of new religious leaders, nationals trained in the Arab world who are more likely to disagree with their predecessors over Islamic education and the role of Kiswahili (Constantin 1993: 188; Parkin 1994, 1995). If the older generation of sheiks are perceived to have compromised their religious responsibilities and/or if the costs of involvement with government are perceived to have been high in relation to benefits, dissension over the existing commitment to the secular status quo will grow. Evidence that dissension exists comes from events in 1990 when the 'Union of Muslim Preachers of Related Religions' (UWAMDI) based at Mtoro Mosque in Dar es Salaam denounced BAKWATA and called for the removal of its leadership, and from a government ban preventing UWAMDI from holding public rallies (Balda 1993: 228ff.).

The religious undercurrent among Sunni Muslims is complicated. On the one hand, structural changes have exacerbated poverty and marginalised a majority of the population. African Muslims appear to be re-evaluating their involvement in and commitment to government programmes which have brought limited benefits and have advanced the interests of better educated Christians and foreign business. At the same time support from Iran - in the form of Islamic literature (e.g. publications, videos), development aid, and assistance channelled through the local Shia Ithna'ashari community - has grown. Nearer to home, Wahhabi reformists 
in Zanzibar have persistently pushed an Islamist agenda of religious reform at the same time that Muslim and other political interests have agitated to increase the island's autonomy from the mainland. Religious currents appear to tap a deep well-spring of discontent about the dislocations associated with political liberalisation and structural adjustment which means that Islamist calls for reform are fundamentally political.

Social and religious cross-currents in Islam, within Zanzibar and with the mainland suggest that Islamist calls for reform/renewal are based in the rivalry between different religious leaders and the state (each of which seeks to make use of Islamic discourses about identity) as well as upon local traditions of popular culture and protest (E. Burke 1988). This is not to say that Islamists elsewhere are uninfluential, but rather, that at present the majority of Sunni Muslims are more concerned with local-national politics and that in this context political protest is articulated partially as a call for reform. In short, popular culture and local political contests result in the invocation of religion (e.g. Islam) and ethnicity to meet the objectives of local leaders. With the collapse of nationalism new forms of protest and collective action appear to be emerging in which protestors draw upon a broad range of ideas and ideologies concerned with social justice including Islam which increasingly informs local cultural understandings (Lubeck 1988).

In Zanzibar the political process has evolved differently. Here local and national issues are intertwined with the fractious nature of parliamentary politics, especially Zanzibar's attempt to contravene the Union constitution. From one perspective, politics revolves around the same set of actors and institutional interests pursuing power and advantage as of old, that is, the entrenched position of CCM and the long-established Zanzibari opposition to CCM, CUF (Chege 1994; van Cranenburgh 1996). The relative strength of both parties altered in recent years due to political realignments on Zanzibar in which the ruling CCM party represented conservative and Islamist values, while CUF assumed an oppositional stance vis-à-vis CCM, Islamists and the mainland while also seeking autonomy for the isles. CCM's handling of the 1995 elections, including its efforts to hamstring opposition parties and its opposition to Zanzibari succession, split the vote between CUF and CCM with the latter unilaterally declaring itself the winner of the elections. ${ }^{12}$ The net effect of the political process has been to 'produce an assertive Islamic movement within and outside CCM' which has allies in Saudi Arabia and the Persian Gulf (Chege 1994: 66).

The bitterly contested fight over of the role of ethnicity, race and religion in Tanzanian politics operates at three levels: the sociocultural (i.e. the production of public identity), the political and the economic. Above all else, the intensity of feeling which infuses this debate concerns which group's definition of culture and identity is to be adopted to define national identity now that the secular nationalist programme has collapsed. As Richard Fox has argued, 'a national culture is always "temporary" because, 
whether antique or modern, its character and puissance are matters of historical practice: they are plastic constructions, not cultural givens' (1990: 4). As Fox and others make clear, ethnicity, racial identity and nationalism are alike not only in that they are deeply felt and durable, but also because they are cultural productions of public identity. As such, they are ideologies which articulate a conception of a common Tanzanian culture which compels individuals into action by (re)defining social boundaries within which new social bonds are produced and/or old ones are recast, a process which generates strong individual commitment (ibid: 7).

Structural adjustment and political liberalisation have set in motion a deep-seated political debate not only over the question of who should benefit from state policies and about the legitimacy of the distributive mechanisms the state should use (Williams 1989: 405). As a result, local and national politics has become hotly contested and has increasingly polarised public attitudes and perceptions. In attempting to make sense of the conflict and to secure their own interests, individuals draw upon current ideas, images and information and participate in different types of social collectivities in pursuit of their objectives (Appadurai 1990).

Economically, local-level conflict is perceived as ethnic rivalry (and may or may not escalate depending upon wider circumstances), whereas regional and national political interests tend to present themselves and the nature of the conflict in more universalistic terms. For example, the increased salience of ethnicity and religion in Tanga (Booth et al. 1993: 115), central Tanzania (Ostberg 1995) and Zanzibar (Parkin 1995) is predominantly concerned with local contestations with key ethnic/religious 'Others'. At the national level, however, the 1995 national elections resulted in a realignment of localnational politics linking notions of ethnicity to a globalised 'post-socialist rhetoric' as locals supported specific political parties (Moore 1997). At each level political discourse increasingly represents its protagonists in stereotypic terms as belonging to a bounded, culture-bearing, homogeneous social group. It is but a short step from the employment of universalist categories as a means of articulating one's perspective to a situation where perceptions of difference become conventions which increasingly govern social relationships.

However, while locals increasingly deploy notions of ethnicity, race and religion in conformity with global structures of common difference, the specific meaning of such terms emerges only in the political arena through the constant realignment of factions, groups and parties (Wilk 1995). The political process also ensures that, in relation to a specific situation or event, each group's interests are defined as one of a pair of dichotomous terms whose essential identity is based on an opposite, specific other (in the process collapsing boundaries between certain social categories). Thus, at the national level conflict over the status of the Union conjoins walala hoi (mainlanders) against warabu (Arabs/Muslims) or Tanzanians against Zanzibaris. However, the relevant dichotomy may contract/expand to 
exclude/include Christian (predominately mainlanders) against Muslim (predominantly Zanzibari) should the issues impinge on 'religion'. Similarly, on the mainland urban conflict tends to be articulated as 'racial' (i.e. between African vs. Asian) or, in the context of participation in development programmes it can assume a 'religious' dimension (i.e. Christian vs. Muslim). Local level conflict involves groups and individuals who occupy the same social space relative to national politics, thus, in the islands Wapemba vs. Waunguja (natives of Pemba and Zanzibar islands, respectively) divide with respect to each other but stand together vis-à-vis the mainland.

\section{Conclusion: citizenship versus fundamentalism?}

The debate in Tanzania as elsewhere in Africa concerning the role of ethnicity, religion and nationalism in national culture is foregrounded in socioeconomic decline and underlying contradictions between civic/territorial and ethnic/cultural conceptions of the state. This uneasy relationship is further complicated by the increasing global connectivity which promotes and sustains the flow of ideas, information, capital and technology within and across national and social boundaries (Appadurai 1990).

From independence until the late 1980s, ethnicity, race and religion were explicitly excluded from national political life because the ruling political party believed they had no role to play in a secular, socialist agenda of kujenga taifa (nation-building) and because to admit their importance could have seriously jeopardised the political union imposed on Zanzibar. However, the failure of ujamma/socialism has eroded the salience of secular nationalism. At the same time, the collapsing authority of the ruling political party and the state coincided with the proliferation of political parties and religious organisations and has helped undermine national institutions.

Elsewhere in the region the failure of nationalism and the post-colonial political programmes built upon it - whether 'socialist' or 'capitalist' - has opened wide cracks in the hegemonic project of the political elite to dominate society and define the nature of national identity with its encoded understandings about citizenship that sustains the legitimacy of the political system. The result is that a new vista of possibilities for contemporary politics and identity formation has emerged in the 1990s which take as their starting point the state and its role in class and ethnic stratification.

In Kenya the legitimacy of the state and elite politics has increasingly been called into question by Arap Moi's deliberate undermining of the National Assembly and attempts to eliminate opposition and dissent (Hornsby and Throup 1992). Moi's efforts to silence his critics, marginalise Kikuyu opponents and build a 'Kalinjin-centric state' has destroyed the Kenyan economy and increased factional strife at a time of rapidly growing 
demographic pressure; it has also provided a window of opportunity through which the IMF and Western donors have attempted to influence Kenyan politics (Chege 1994).

Similarly the multiparty elections held in Malawi in 1994 were the first since the demise of Banda and his repressive party (Kaspin 1995). As in Kenya, the one-party state led to the enrichment of a class of politicians and an evident development bias towards Banda's own ethnic group. Banda's attempt to model Malawi national identity on Chewa culture failed to integrate two-thirds of the population, in the process contributing to political unrest, economic stagnation and the development of a viable political opposition.

Superficially the situation in Ethiopia would appear quite different from Tanzania, Kenya and Malawi (Zegeye and Abate 1996; Gilkes 1996). However, the political programme being pursued by the Ethiopian People's Revolutionary Democratic Front (the EPRDF), the name of the Tigrayandominated coalition of forces which ousted the Mengistu regime in 1991, is faced with exactly the same concerns, namely: the need to legitimate its specific objectives as a truly national programme (in the face of potentially powerful nationalist opposition forces), and to institutionalise itself through constitutional reform, the use of police and military force, and the creation of alliances with regional elites to compete in the electoral process. Here the basis of 'national' identity is closely associated with specific ethnonationalist interests which makes the EPRDF project particularly problematic because non-Tigrayans are unwilling to buy into what they see as a Tigrayan ethnic agenda. Nominally, the Ethiopian state has always combined elements of civic identity - common rights, a unified territory, a single economy - with certain ethnic and religious notions to define the nation. However, this uneasy combination of civic and ethnic concepts has always been manipulated to suit the group in power, and has contributed to the failure to develop a plural concept of nation based upon a genuinely shared public culture in which no one group is privileged. Seen in these terms, EPRDF efforts are likely to depend on the continued use of force to ensure compliance with policy, potentially a very high price which has brought down previous regimes.

The key issues concerns the role of the one-party state and the sociocultural basis upon which such regimes have sought to construct the 'nation'. In merely seeking to shore up an increasingly narrow political base and stifle the opposition, one-party states have contributed directly to the expansion of political conflict and instability by rendering the formal political system redundant as a means of influencing policy, ensuring political accountability, and integrating the population into the political system. Instead of seeking to promote political plurality through the establishment of accountable institutions, the state has been used to recruit and manage a political elite, while national institutions have become little more than talking shops. Tanzania, unlike Ethiopia, Kenya or Malawi, 
initially sought to construct the nation on a secular - non-ethnic and nonreligious - basis; it seems, however, that a pragmatic concern with power on the part of CCM, played out in the context of economic decline, undermined institutional accountability and public trust in the stated objectives of national programmes.

Jonathan Friedman has argued that cyclical expansions and contractions of the world system are the fundamental dynamic driving the process of social and cultural fragmentation in states like Tanzania which are characterised by ethnic and nationalist ferment (1989). While East Africa may be peripheral to capital accumulation in North America and Europe, the above discussion indicates the key role played in this process by a national elite whose mismanagement of the state has contributed directly to economic decline and escalating political conflict. The legitimacy of elite politics has everywhere come under close scrutiny and attack led increasingly by middle-class beneficiaries of state policies who are playing an increasingly pivotal role in opposition politics.

In Tanzania, current fears have their basis in growing social inequality and a concern that changes in the status quo could irretrievably disadvantage those who are poorly organised. A perception of relative advantage/ disadvantage fuels uncertainty, which feeds into new visions of the future and attempts to create new organisations and ideologies to replace older, discredited ones. Collective perceptions of the past together with contemporary calculations of self-interest strongly influence social action, unleashing forces which may well undermine political stability.

In a climate of political and economic liberalisation, Tanzanians are increasingly confronting one another in social, economic and political arenas on unequal terms, the perception of which feeds into increasing efforts, especially by the elite, to organise on the basis of ideas about ethnicity and religion to secure or preserve advantage. The declining authority of the state and the re-emergence of ethnicity and religion as significant factors in current sociopolitical realignments strongly suggests not only that the one-party state, even if it has the backing of the military, will be unable to manage national politics and, further, that no government, whatever its composition, is likely to secure sufficient national support for its policies unless and until steps are taken to ensure that politicians and political institutions are publicly accountable and that political decisionmaking is based on the development of a civic public culture.

\section{Notes}

1 Source: http://:csf.Colorado.EDU:70/00/I/960414.tan. Failing_Education_System.

2 Source: Daily News (here after DN) 11 August 1993, 'Death threats case postponed'.

3 DN, 25 January 1995, p. 3; and 26 January 'Saturday riots - Dar police question Mtikila'.

4 DN 28 January 1995, front page leader. "When asked to make a plea he said "Ni ndoto, siyo $k w e l i$ " (this is a dream, it is not true). Prosecution objected to bail'. 
5 DN 28 January 1995 p. 3; DN 2 February 1995: 'Parents allege tribalism in Songea School'; DN 11 February, 'Ikwiriri project impresses Iran', respectively.

6 DN 10 April 1993, 'Tanzanians mark Good Friday'.

7 DN 10 July 1993, 'Pork shops: witnesses disallowed'; DN 17 April 1993 'Sheik Yahya in court - nine youths face petrol bomb charge'.

8 DN 24 April 1993, '12 more Muslim zealots charged'; but see a photo of the demonstration printed on the front page of The Tribune of 5-11 August 1994, showing hundreds of people peacefully gathered at the demonstration.

9 DN 8 May 1993, 'Demonstration charges against 24 withdrawn', and 'All is set for BAKWATA meeting'.

10 Source: http://:csf.Colorado.EDU:70/00/1940915.tan.Islamic fundamentalism.

11 DN 18 August 1994, 'Court asked to recall Mrema'.

12 Cf. 'Zanzibar's ballot hopes betrayed', The Guardian, 4 November 1996, p. 12.

\section{References}

Abebe, Z. and D. Abate. 1996. 'Nationalism, democracy and development in Ethiopia', in D. Dwyer and D. Drakakis-Smith (eds.), Ethnicity and Development, Geographical Perspectives. Chichester: $J$. Wiley and Sons.

Amiji, H. 1969.'The Asian communities', in J. Kritzeck and W. Lewis. (eds.), Islam in Africa. NY: Van Nostrand-Reinhold.

Anthony, D. H. 1983. 'Culture and society in a town in transition: a people's history of Dar es Salaam'. Ph.D. University of Wisconsin-Madison.

Appadurai, A. 1990. 'Disjuncture and difference in the global cultural economy', in M. Featherstone (ed.), Global Culture. London: Sage.

Balda, J. 1993. 'The role of Kiswahili in East African Islam', in L. Brenner (ed.), Muslim Identity and Social Change in Sub-Saharan Africa. London: Hurst.

Blommaert, J. 1996. 'Language and nationalism: comparing Flanders and Tanzania', Nations and Nationalism 2, 2: 235-56.

Boeson, J., B. Storgard Madsen and T. Moody. 1977. Ujamaa - Socialism from above. Uppsala: Scandinavian Institute of African Studies.

Booth, D. et al. 1993. 'Social, economic and cultural change in contemporary Tanzania: a people-oriented focus'. Report to the Swedish International Development Agency, Stockholm. The Development Studies Unit, Department of Social Anthropology, Stockholm University.

Burke, E. 1988. 'Islam and social movements: methodological reflections', in E. Burke and I. Lapidus (eds.), Islam, Politics and Social Movements. London: I.B. Taurus.

Burke, F. 1964. 'Tanganyika: the search for Ujamaa', in W. H. Friedland and C. G. Rosberg (eds.), African Socialism. Stanford: Stanford University Press.

Campbell, J. forthcoming. 'Race, class and community in colonial Dar es Salaam', in C. Creighton (ed.), Gender, Family \& Work in Tanzania. Aldershot: Avebury.

Campbell, J., J. Mwami and M. Ntukula. 1995. 'Urban social organisation: an exploration of kinship, social networks, gender relations, household and community in Dar es Salaam', in C. Creighton and C. K. Omari (eds.), Gender, Family and Household in Tanzania. Aldershot: Avebury.

Chande, A. N. 1993. 'Muslims and modern education in Tanzania', Journal Institute of Muslim Minority Affairs 14: 1 and 2: 1-16.

Chege, M. 1994. 'The return of multi-party politics', in J. Barkan (ed.), Beyond Capitalism v. Socialism in Kenya and Tanzania. London: L. Rienner.

Constantin, F. 1993. 'Leadership, Muslim identities and East African politics: tradition, bureaucratization and communication', in L. Brenner (ed.), Muslim Identity and Social Change in Sub-Saharan Africa. London: Hurst. 
Court, D. 1979. 'The education system as a response to inequality', in J. D. Barkan and J. J. Okumu (eds.), Politics and Public Policy in Kenya and Tanzania. London: Heineman.

Elmasri, F. H. 1987. 'Sheik al-Amin bin Ali al-Mazrui and the Islamic intellectual tradition in East Africa', Journal Institute of Muslim Minority Affairs 8, 2: 229-37.

Fox, R. (ed.) 1990. 'Introduction', in Nationalist Identities and the Production of National Cultures. Washington, DC: American Ethnological Society Monograph, series no. 2.

Friedman, J. 1989. 'Culture, identity and world process', Review 12, 1: 51-69.

Gilkes, P. 1996. 'Ethiopia - recent history', in Africa South of the Sahara. 26th edn. London: Europa Publications.

Gilsenan, M. 1982. Recognizing Islam. London: Croom Helm.

Hedlund, S. and M. Lundahl. 1989. Ideology as a Determinant of Economic Systems: Nyerere and Ujamaa in Tanzania. Uppsala: Scandinavian Institute of African Studies.

Helleiner, G. 1987. 'Stabilization, adjustment, and the poor', World Development 15, 12: 1499-513.

Hornsby, C. and D. Throup. 1992. 'Elections and political change in Kenya', Journal of Commonwealth \& Comparative Politics 30, 2: 172-99.

Iliffe, J. 1979. A Modern History of Tanganyika. Cambridge: Cambridge University Press.

Kaduma, L. M. 1974. 'Twenty years of TANU "education"', in G. Ruhumbika (ed.), Towards Ujamma: Twenty Years of TANU Leadership. Dar es Salaam: East African Literature Bureau.

Kaspin, D. 1995. 'The politics of ethnicity in Malawi's democratic transition', The Journal of Modern African Studies 33, 4: 595-620.

Khamis, A. M. 1974. 'Swahili as a national language', in G. Ruhumbika (ed.), Towards Ujamma: Twenty Years of TANU Leadership. Dar es Salaam: East African Literature Bureau.

Lockwood, M. 1989. 'Fertility and labour in Rufiji District, Tanzania'. Ph.D. thesis, Oxford University.

Lubeck, P. 1988. 'Islamic political movements in Northern Nigeria: the problem of class analysis', in E. Burke and I. Lapidus (eds.), Islam, Politics and Social Movements. London: I. B. Taurus.

Mbuguni, L. and G. Ruhumbika. 1974. 'TANU and national culture', in G. Ruhumbika (ed.), Towards Ujamma: Twenty Years of TANU Leadership. Dar es Salaam: East African Literature Bureau.

Moore, S. F. 1997. 'Post-socialist micro-politics: Kilimanjaro, 1993', Africa 66, 4: 587-606.

Nimtz, A. 1980. Islam and Politics in East Africa: The Sufi Order of Tanzania. Minneapolis: University of Minnesota.

Nyerere, J. 1964. 'Ujamaa', in W. H. Friedland and C. G. Rosberg (eds.), African Socialism. Stanford: Stanford University Press.

Oliver, R. 1970. The Missionary Factor in East Africa. London: Longman.

Ostberg, W. 1995. Land is Coming Up: The Burunge of Central Tanzania and their Environment. Stockholm Studies in Social Anthropology, Department of Social Anthropology, University of Stockholm.

Parkin, D. 1994. 'Islam, symbolic hegemony and the problem of bodily expression', in S. Heald and A. Deluz (eds.), Anthropology and Psychoanalysis. London: Routledge.

Parkin, D. 1995. 'Blank banners and Islamic consciousness in Zanzibar', in A. P. Cohen and N. Rapport (eds.), Questions of Consciousness. London: Routledge.

Pouwels, R. 1987. Horn and Crescent: Cultural change and Traditional Islam on the East African Coast, 800-1900. Cambridge: Cambridge University Press.

Sanneh, L. 1994. 'Translatability in Islam and Christianity in Africa: a thematic approach', in T. Blakely et al. (eds.), Religion in Africa. London: Heineman and J. Currey.

Schildknecht, F. 1969. 'Tanzania', in J. Kritzeck and W. Lewis (eds.), Islam in Africa. NY: Van Nostrand-Reinhold.

Scotton, J. 1978. 'Tanganyika's African press, 1937-60: a nearly forgotten pre-independence forum', African Studies Review 21, 1: 1-18. 
Shivji, I. 1986. Law, State and the Working Class in Tanzania. London: J. Currey and Heineman Books.

Smith, A. D. 1991. National Identity. Harmondsworth: Penguin.

Sperling, D. 1993. 'Rural madrasas of the Southern Kenyan coast, 1971-92', in L. Brenner (ed.), Muslim Identity and Social Change in Sub-Saharan Africa. London: Hurst.

Trimingham, J. S. 1964. Islam in East Africa. Oxford: Clarendon Press.

Tripp, A. M. 1997. Changing the Rules: The Politics of Liberalization and the Urban Informal Economy in Tanzania. Berkeley: University of California.

Van Cranenburgh, O. 1996. 'Tanzania's 1995 multi-party elections', Party Politics 2, 4: 535-47.

Versteijnen, Fr. 1968. The Catholic Mission of Bagamoyo. 2nd edn 1991. Bagamoyo: A. K. Zuber and COD Saarbrucken.

Wilk, P. 1995. 'Learning to be local in Belize: global systems of common difference', in D Miller (ed.), Worlds Apart: Modernity Through the Prism of the Local. London: Routledge.

Williams, B. F. 1989. 'A class act: anthropology and the race to nation across ethnic terrain', Annual Review of Anthropology 18: 401-44.

Yeager, R. 1989. Tanzania: An African Experiment. Boulder, CO: Westview.

Zegeye, A. and D. Abate. 1996. 'Nationalism, democracy and development in Ethiopia', in D. Dwyer and D. Drakakis-Smith (eds.), Ethnicity and Development: Geographical Perspectives. New York: J. Wiley \& Sons. 